\title{
Are general practice characteristics predictors of good glycaemic control in patients with diabetes? A cross-sectional study
}

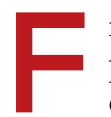
inding ways to better care for people with diabetes and other chronic conditions is a priority for the Australian health system. It is notable that five of the nine national health priority areas established by Australian governments $^{1}$ are chronic conditions (diabetes, mental health, asthma, arthritis, obesity and dementia). Increasing survival of patients with cancer (one of the three other priority areas, together with cardiovascular health and injury prevention) means that this could also be considered a chronic condition.

Diabetes is one of the fastest growing chronic conditions in Australia, with National Health Survey reports showing an increase in prevalence from $1.3 \%$ in $1989-90$ to $4.5 \%$ in 2011-12. ${ }^{2}$ This increase is probably linked with the ageing of our population, rising levels of obesity, and greater life expectancy for those with diabetes. $^{2}$ Diabetes expenditure is also growing rapidly, with the annual costs (after adjusting for inflation) rising from $\$ 811$ million in $2000-01$ to $\$ 1507$ million in 2008-09, an average annual growth rate of $10 \%{ }^{2}$

Adrian J Esterman PhD, MSC, BSc(Hons) ".

Tim Fountaine $\mathrm{MBChB}, \mathrm{PhD}$

Robyn McDermott

MBBS, MPH, PhD²,

1 University of South Australia,

Adelaide, SA

2 Centre for Research

Excellence in

Chronic Disease Prevention, James Cook University. Cairns, QLD.

3 McKinsey \& $\mathrm{CO}$ Sydney, NSW

4 South Australian Health and Medical Research Institute, Adelaide, SA.

Adrian.Esterman@ unisa.edu.au

doi: 10.5694/mjal5.00739
Recent studies have shown that there are opportunities for improving care for those with diabetes. For example, the CareTrack Australia study, which explored the appropriateness of the care provided in general practice, found that only $63 \%$ of patients with Further, data from the Australian Institute of Health and Welfare Institute indicate that in 2009-10 only $18 \%$ of patients with diabetes had completed the recommended annual cycle of care (ACC). ${ }^{4}$

It is clear that there are many possible reasons why an individual patient might not receive optimal care. For example, a patient might have several comorbid conditions that diabetes received optimal care. ${ }^{3}$

Abstract

Objectives: To determine whether certain characteristics of general practices are associated with good glycaemic control in patients with diabetes and with completing an annual cycle of care (ACC).

Research design and methods: Our cross-sectional analysis used baseline data from the Australian Diabetes Care Project conducted between 2011 and 2014. Practice characteristics were self-reported. Characteristics of the patients that were assessed included glycaemic control

$\left(\mathrm{HbA}_{\mathrm{lc}}\right.$ level $\left.\leq 53 \mathrm{mmol} / \mathrm{mol}\right)$, age, sex, duration of diabetes, socioeconomic disadvantage (SEIFA) score, the complexity of the patient's condition, and whether the patient had completed an ACC for diabetes in the past 18 months. Clustered logistic regression was used to establish predictors of glycaemic control and a completed ACC.

Results: Data were available from 147 general practices and 5455 patients with established type 1 or type 2 diabetes in three Australian states. After adjustment for other patient characteristics, only the patient completing an ACC was statistically significant as a predictor of glycaemic control $(P=0.011)$. In a multivariate model, the practice having a chronic disease-focused practice nurse $(P=0.036)$ and running educational events for patients with diabetes $(P=0.004)$ were statistically significant predictors of the patient having complete an ACC.

Conclusions: Patient characteristics are moderately good predictors of whether the patient is in glycaemic control, whereas practice characteristics appear to predict only the likelihood of patients completing an ACC. The ACC is an established indicator of good diabetes management. This is the first study to report a positive association between having completed an ACC and the patient being in glycaemic control.

militate against the use of a recommended medication. Patients themselves might not adhere to the recommended therapy, or be able to afford a prescribed medication. The workloads of individual general practitioners differ, and the amount of training in chronic disease management is variable.

Practice characteristics, such as the employment of a practice nurse or the use of medical software, might also affect the appropriateness of care. Studies of the relative contributions of these factors have produced mixed results. For example, a study of 422 general practices providing care for 154945 patients with diabetes in the United Kingdom found no relationship between practice size and the quality of diabetes management (defined as achieving $\mathrm{HbA}_{1 \mathrm{c}}$ levels of $53 \mathrm{mmol} / \mathrm{mol}$ or less). ${ }^{5}$
An American study of 40 medical groups found that the practice health systems (including formal quality assurance activities and data feedback), clinical information systems (including a diabetes registry), and decision support (including clinical guidelines, clinician prompts for diabetes) were all associated with patients with diabetes having $\mathrm{HbA}_{1 \mathrm{c}}$ levels of $64 \mathrm{mmol} / \mathrm{mol}$ or less. ${ }^{6}$ It is notable that they found no association between glycaemic control and the practice having a diabetic educator, a dedicated specialist diabetic nurse, a primary care team, patient reminders, or self-management training for patients.

A systematic review of the impact on glycaemic control of 11 different categories of practice quality improvement found that most produced small to modest benefits for glycaemic control. ${ }^{7}$ 
A study of 10 health centres in the Netherlands (45 GPs) found that the quality of care for patients with diabetes was higher if the centre had a diabetes education program, yearly medical check-ups by both the GP and a nurse practitioner, and structured follow-ups.

A 2009 Australian study found that a GP service incentive payment (SIP) scheme for improving chronic disease management increased the probability of a GP requesting an assessment of $\mathrm{HbA}_{1 \mathrm{c}}$ levels by $20 \%$. ${ }^{9}$ A similar study found that practices receiving practice nurse support were more likely to claim SIP payments for diabetes care, whereas practice size, diabetes activities, and the sex and age of the GPs were not associated with SIP payments. ${ }^{10}$

In this article, we present the results of our analysis of baseline data collected as part of the Diabetes Care Project (DCP), a federal governmentfunded project conducted between 2011 and 2014 to evaluate whether changes to the way in which primary care is organised and funded might improve care for people with diabetes. ${ }^{11}$ The DCP was a pragmatic clustered, three-armed, randomised controlled trial that evaluated the efficacy of coordinated patient care and flexible funding for GPs in the management of patients with diabetes. Clustering was at the level of the general practice. The three arms of the study were the control group (usual care), intervention group 1 (installation of the online chronic disease management support tool $c d m N^{12}$ and access to training and capability building), and intervention group 2 (installation of $c d m N e t$, altered funding arrangements, provision of a care facilitator, and access to training and capability building). The primary outcome measure was defined as a change in patient $\mathrm{HbA}_{1 \mathrm{c}}$ levels at the end of the trial. Participants were included if they were at least 18 years old, had established type 1 diabetes mellitus (diagnosed at least 12 months ago) or newly diagnosed or established type 2 diabetes mellitus, and had the capacity to provide informed consent. Exclusion criteria included having a terminal illness or dementia, being pregnant or planning to become pregnant, and participating in the Coordinated Veterans Care program.

Our aim was to assess whether the characteristics of GP practices were associated with good glycaemic control in patients with diabetes and with completing an ACC. The dataset for our cross-sectional study, in contrast to that used in the DCP, was not risk-stratified, and we excluded newly diagnosed patients. In addition, our study includes the results of a separate survey of GP practices that was not part of the DCP study protocol.

\section{Methods}

A full medical history was obtained and patient demographic data were collected at baseline, as well as data on a number of clinical indicators, including $\mathrm{HbA}_{1 \mathrm{c}}$ levels. This information was obtained from the medical records in each practice. Practice characteristics were collected by telephone interview with the relevant staff of each practice (Box 1). Glycaemic control was defined as having an $\mathrm{HbA}_{1 \mathrm{c}}$ level of $53 \mathrm{mmol} / \mathrm{mol}$ or less.
The ACC is a measure of the clinical management of diabetes according to Australian national guidelines. Completion of the ACC enables GPs to submit a claim to Medicare for the costs of managing a patient with diabetes. For the ACC to be complete, all of the following actions need to have been undertaken: annual measurement of $\mathrm{HbA}_{1 \mathrm{c}}$ level; comprehensive eye examination every two years; twice yearly assessments of body mass index, blood pressure and feet; annual measurement of total cholesterol, triglyceride and high-density lipoprotein cholesterol levels; and annual test for microalbuminuria. Information on whether the ACC had been completed in the 18 months before starting the DCP was also available from Medicare as part of the baseline dataset.

The original sample size for the DCP was based on its being a three-armed, clustered, randomised controlled trial that compared changes in $\mathrm{HbA}_{1 \mathrm{c}}$ levels in the three groups during the study period. We excluded all newly diagnosed patients in this sample, as they would not have had time to have a completed ACC, leaving a sample size of 5455 patients. Logistic regression of a binary response variable $(\mathrm{Y})$ on a binary independent
1 Practice characteristics assessed for this study

- Practice location

- Practice size

- Practice has a practice nurse

- Practice has a chronic disease-focused practice nurse

- Practice currently uses chronic disease management software

- Corporate practice (ie, part of a larger group of practices)

- Allied health professionals located in the practice

- Practice participated in the Australian collaborative quality improvement program in the past 24 months

- Practice takes part in audit and feedback

- Practice has dedicated staff member who coordinates care or manages cases

- Practice has regular multidisciplinary team meetings

- Practice has regular staff education events

- Practice uses shared electronic medical records with care team

- Practice has education events for patients with diabetes

- Practice has formal motivation and self-management education activities for patients with chronic diseases 
variable $(X)$ with a sample size of 1835 observations (of which $50 \%$ are in the group $X=0$ and $50 \%$ are in the group $X=1$ ) would achieve $80 \%$ power at $P<0.05$ for detecting a difference corresponding to an odds ratio of 1.3. To allow for the clustered design, we assumed an intraclass correlation coefficient of 0.05 , providing a design effect of approximately 3; this was equivalent to a required sample size of 5505 (ie, $3 \times 1835)$ individuals, close to the actual sample size.

Practice predictors of good glycaemic control were assessed at an unadjusted univariate level, and after adjustment for patient age, sex, duration of diabetes, patient complexity (a dichotomous variable based on macro- and microvascular complications of diabetes, and comorbid renal disease and depression), and the Australian Bureau of Statistics Socio-Economic Indexes for Areas (SEIFA) score for relative socio-economic disadvantage. ${ }^{13}$ Odds ratios and $95 \%$ confidence intervals were calculated using clustered logistic regression models.

Practice predictors of a completed ACC were initially assessed at the univariate level, and then in a multivariate model that included all variables significant at $P \leq 0.05$ in the univariate analyses. Adjustment for age, sex, duration of diabetes, patient complexity and SEIFA score was undertaken for all models, including the multivariate model, but these adjustments had little effect on the results; these analyses are therefore not presented in this article. All models involving patient-level data were adjusted for clustering by practice. Stata 14 (StataCorp) was used for all statistical analyses.

The study protocol was approved by the human research ethics committees of the Department of Health and Ageing (application number 15/2011), the Department of Human Services (2010/Co09591), the Australian Institute of Health and Welfare (EC 2011/4/38), SA Health (HREC 474/09/2014) and Queensland Health (HREC/11/QTDD/65), and by the Aboriginal Health Research Ethics Committee
(Aboriginal Health Council of South Australia; reference 04-11-471). On the basis of the above approvals, the Department of Health, Victoria, determined that the study did not need review by their Human Research Ethics Committee.

\section{Results}

Data were available for 5455 patients and for 147 of 150 medical practices $(98 \%)$. The mean age of the patients was $65.3 \pm 11.6$ years; $55.9 \%$ were men. The median time since diagnosis of diabetes was 9 years (interquartile range, 4-15 years). In general, these data were consistent with data for the general Australian population of people with diabetes. The enrolled GP practices had fewer solo GPs and more practice nurses than the national average. ${ }^{11}$

Of the 5455 patients, $55.0 \%$ (95\% CI, $53.7 \%-56.4 \%$ ) had good glycaemic control $\left(\mathrm{HbA}_{1 \mathrm{c}} \leq 53 \mathrm{mmol} / \mathrm{mol}\right)$; $37.0 \%(95 \% \mathrm{CI}, 35.8 \%-38.3 \%)$ had completed an ACC in the past 18 months.

Using logistic regression of glycaemic control on practice identification number treated as a dummy variable, the McKelvey and Zavoina pseudo$R^{2}$ indicated that GP practice accounted for $5 \%$ of the variability in glycaemic control. The patient characteristics of age, sex, duration of diabetes, condition complexity and SEIFA score together accounted for $13.5 \%$ of variability in glycaemic control.

Box 2 presents data on the relationship between each of the practice characteristic variables and glycaemic control. Although the patient having a completed ACC is, strictly speaking, a patient characteristic, it is nonetheless a measure of practice quality and has therefore been included in this table.

In the unadjusted analysis, only the practice having regular multidisciplinary team meetings (odds ratio [OR], 1.16;95\% CI, 1.03-1.31) and the patient having completed an ACC (OR, 1.21; 95\% CI, 1.07-1.37) were significantly associated with patients being in glycaemic control. After adjustment for age, sex, duration of diabetes, condition complexity and SEIFA, only the association with the patient having completed an ACC remained statistically significant.

Data for predictors of the patient having completed an ACC in the past 18 months are shown in Box 3. At the univariate level, the practice having a chronic disease-focused nurse (OR, $2.01 ; 95 \% \mathrm{CI}, 1.07-3.77)$, the practice having regular staff educational events (OR, 1.68; 95\% CI, 1.03-2.73), and the practice offering diabetes education events for patients (OR, $1.92 ; 95 \%$ CI, 1.21-3.06) were all statistically significantly associated with completion of an ACC. In the multivariate analysis, however, only the practice having a chronic diseasefocused nurse and the practice running diabetes education events for patients were statistically significant.

\section{Discussion}

It is notable that neither having at least one practice nurse nor a chronic disease-focused practice nurse were directly associated with good glycaemic control in patients with diabetes. A review of the literature identifies mixed findings about the value of practice nurses. For example, a 2003 Cochrane review concluded that the availability of a diabetes specialist nurse or nurse case manager may improve patients' diabetic control for short periods, but there was not enough evidence to demonstrate this effect in the longer term. ${ }^{14}$ On the other hand, a retrospective cohort study of 397 patients with type 2 diabetes recruited from five general practices in the Netherlands found that delegating diabetes care to a practice nurse led to improvements in diabetes care, including a statistically significant drop in $\mathrm{HbA}_{1 \mathrm{c}}$ levels. ${ }^{15}$ Finally, an observational study of 193 Danish general practices and 12960 patients with type 2 diabetes found that the proportion of patients with $\mathrm{HbA}_{1 \mathrm{c}}$ levels of $64 \mathrm{mmol} / \mathrm{mol}$ or more was lower in practices with well implemented, nurse-led type 2 diabetes consultations. ${ }^{16}$ 
2 Practice characteristics associated with good glycaemic control: univariate models

\begin{tabular}{|c|c|c|c|c|c|c|c|c|c|}
\hline \multirow[b]{2}{*}{ Variable } & \multirow[b]{2}{*}{ Category } & \multicolumn{2}{|c|}{$\begin{array}{c}\mathrm{HbA}_{1 \mathrm{c}} \\
>53 \mathrm{mmol} / \mathrm{mol}\end{array}$} & \multicolumn{2}{|c|}{$\begin{array}{c}\mathrm{HbA}_{1 \mathrm{c}} \\
\leq 53 \mathrm{mmol} / \mathrm{mol}\end{array}$} & \multirow{2}{*}{$\begin{array}{l}\text { Odds } \\
\text { ratio }\end{array}$} & \multirow{2}{*}{$\begin{array}{c}95 \% \\
\mathrm{Cl} \text { for } \\
\text { odds ratio }\end{array}$} & \multirow[b]{2}{*}{$P *$} & \multirow[b]{2}{*}{$P^{\dagger}$} \\
\hline & & $n$ & $\%$ & $n$ & $\%$ & & & & \\
\hline Metropolitan practice & $\begin{array}{l}\text { No } \\
\text { Yes }\end{array}$ & $\begin{array}{l}706 \\
1743\end{array}$ & $\begin{array}{l}46.3 \% \\
44.4 \%\end{array}$ & $\begin{array}{r}820 \\
2186\end{array}$ & $\begin{array}{l}53.7 \% \\
55.6 \%\end{array}$ & $\begin{array}{l}1.00 \\
1.08\end{array}$ & $0.93-1.25$ & 0.310 & 0.470 \\
\hline Practice size & $\begin{array}{l}1-2 \mathrm{GPs} \\
\geq 3 \mathrm{GPs}\end{array}$ & $\begin{array}{c}559 \\
1882\end{array}$ & $\begin{array}{l}45.5 \% \\
44.7 \%\end{array}$ & $\begin{array}{c}670 \\
2327\end{array}$ & $\begin{array}{l}54.5 \% \\
55.3 \%\end{array}$ & $\begin{array}{l}1.00 \\
1.03\end{array}$ & $0.88-1.21$ & 0.704 & 0.413 \\
\hline Practice nurse & $\begin{array}{l}\text { No } \\
\text { Yes }\end{array}$ & $\begin{array}{c}408 \\
2002\end{array}$ & $\begin{array}{l}44.7 \% \\
44.9 \%\end{array}$ & $\begin{array}{l}504 \\
2462\end{array}$ & $\begin{array}{l}55.3 \% \\
55.1 \%\end{array}$ & $\begin{array}{l}1.00 \\
1.00\end{array}$ & $0.82-1.21$ & 0.965 & 0.575 \\
\hline Chronic disease-focused nurse & $\begin{array}{l}\text { No } \\
\text { Yes }\end{array}$ & $\begin{array}{c}440 \\
2009\end{array}$ & $\begin{array}{l}48.1 \% \\
44.2 \%\end{array}$ & $\begin{array}{c}474 \\
2532\end{array}$ & $\begin{array}{l}51.9 \% \\
55.8 \%\end{array}$ & $\begin{array}{c}1.00 \\
1.17\end{array}$ & $0.95-1.44$ & 0.135 & 0.375 \\
\hline $\begin{array}{l}\text { Chronic care planning software } \\
\text { already used }\end{array}$ & $\begin{array}{l}\text { No } \\
\text { Yes }\end{array}$ & $\begin{array}{l}1589 \\
830\end{array}$ & $\begin{array}{l}45.3 \% \\
44.3 \%\end{array}$ & $\begin{array}{r}1918 \\
1042\end{array}$ & $\begin{array}{l}54.7 \% \\
55.7 \%\end{array}$ & $\begin{array}{l}1.00 \\
1.04\end{array}$ & $0.90-1.20$ & 0.593 & 0.383 \\
\hline Corporate practice & $\begin{array}{l}\text { No } \\
\text { Yes }\end{array}$ & $\begin{array}{l}2142 \\
240\end{array}$ & $\begin{array}{l}45.1 \% \\
43.2 \%\end{array}$ & $\begin{array}{c}2612 \\
316\end{array}$ & $\begin{array}{l}54.9 \% \\
56.8 \%\end{array}$ & $\begin{array}{l}1.00 \\
1.08\end{array}$ & $0.91-1.29$ & 0.392 & 0.466 \\
\hline Co-located allied health professionals & $\begin{array}{l}\text { No } \\
\text { Yes }\end{array}$ & $\begin{array}{l}1375 \\
1074\end{array}$ & $\begin{array}{l}45.3 \% \\
44.4 \%\end{array}$ & $\begin{array}{l}1660 \\
1346\end{array}$ & $\begin{array}{l}54.7 \% \\
55.6 \%\end{array}$ & $\begin{array}{l}1.00 \\
1.04\end{array}$ & $0.90-1.19$ & 0.596 & 0.634 \\
\hline $\begin{array}{l}\text { Practice involved in quality } \\
\text { improvement collaboration }\end{array}$ & $\begin{array}{l}\text { No } \\
\text { Yes }\end{array}$ & $\begin{array}{c}1626 \\
816\end{array}$ & $\begin{array}{l}45.6 \% \\
43.7 \%\end{array}$ & $\begin{array}{l}1939 \\
1051\end{array}$ & $\begin{array}{l}54.4 \% \\
56.3 \%\end{array}$ & $\begin{array}{l}1.00 \\
1.08\end{array}$ & $0.93-1.26$ & 0.329 & 0.839 \\
\hline Practice has audit and feedback & $\begin{array}{l}\text { No } \\
\text { Yes }\end{array}$ & $\begin{array}{l}1184 \\
1255\end{array}$ & $\begin{array}{l}44.4 \% \\
45.5 \%\end{array}$ & $\begin{array}{l}1483 \\
1502\end{array}$ & $\begin{array}{l}55.6 \% \\
54.5 \%\end{array}$ & $\begin{array}{l}1.00 \\
0.96\end{array}$ & $0.83-1.09$ & 0.512 & 0.692 \\
\hline $\begin{array}{l}\text { Practice has dedicated case } \\
\text { management }\end{array}$ & $\begin{array}{l}\text { No } \\
\text { Yes }\end{array}$ & $\begin{array}{l}1146 \\
1293\end{array}$ & $\begin{array}{l}44.2 \% \\
45.7 \%\end{array}$ & $\begin{array}{l}1448 \\
1537\end{array}$ & $\begin{array}{l}55.8 \% \\
54.3 \%\end{array}$ & $\begin{array}{l}1.00 \\
0.94\end{array}$ & $0.82-1.08$ & 0.376 & 0.436 \\
\hline $\begin{array}{l}\text { Practice has regular multidisciplinary } \\
\text { team meetings }\end{array}$ & $\begin{array}{l}\text { No } \\
\text { Yes }\end{array}$ & $\begin{array}{c}1726 \\
618\end{array}$ & $\begin{array}{l}46.0 \% \\
42.4 \%\end{array}$ & $\begin{array}{c}2028 \\
839\end{array}$ & $\begin{array}{l}54.0 \% \\
57.6 \%\end{array}$ & $\begin{array}{l}1.00 \\
1.16\end{array}$ & $1.03-1.31$ & 0.027 & 0.226 \\
\hline Practice has regular staff education & $\begin{array}{l}\text { No } \\
\text { Yes }\end{array}$ & $\begin{array}{l}1067 \\
1372\end{array}$ & $\begin{array}{l}45.2 \% \\
44.8 \%\end{array}$ & $\begin{array}{r}1291 \\
1694\end{array}$ & $\begin{array}{l}54.8 \% \\
55.2 \%\end{array}$ & $\begin{array}{l}1.00 \\
1.02\end{array}$ & $0.89-1.17$ & 0.774 & 0.877 \\
\hline $\begin{array}{l}\text { Practice uses shared electronic } \\
\text { medical records }\end{array}$ & $\begin{array}{l}\text { No } \\
\text { Yes }\end{array}$ & $\begin{array}{l}1551 \\
894\end{array}$ & $\begin{array}{l}44.9 \% \\
44.9 \%\end{array}$ & $\begin{array}{r}1901 \\
1099\end{array}$ & $\begin{array}{l}55.1 \% \\
55.1 \%\end{array}$ & $\begin{array}{l}1.00 \\
1.00\end{array}$ & $0.86-1.16$ & 0.969 & 0.944 \\
\hline $\begin{array}{l}\text { Practice has patient diabetes } \\
\text { education events }\end{array}$ & $\begin{array}{l}\text { No } \\
\text { Yes }\end{array}$ & $\begin{array}{l}1719 \\
703\end{array}$ & $\begin{array}{l}44.8 \% \\
45.2 \%\end{array}$ & $\begin{array}{l}2117 \\
852\end{array}$ & $\begin{array}{l}55.2 \% \\
54.8 \%\end{array}$ & $\begin{array}{l}1.00 \\
0.98\end{array}$ & $0.83-1.16$ & 0.851 & 0.198 \\
\hline $\begin{array}{l}\text { Practice has self-management } \\
\text { activities }\end{array}$ & $\begin{array}{l}\text { No } \\
\text { Yes }\end{array}$ & $\begin{array}{r}1518 \\
921\end{array}$ & $\begin{array}{l}45.2 \% \\
44.6 \%\end{array}$ & $\begin{array}{l}1840 \\
1145\end{array}$ & $\begin{array}{l}54.8 \% \\
55.4 \%\end{array}$ & $\begin{array}{l}1.00 \\
1.03\end{array}$ & $0.89-1.18$ & 0.729 & 0.913 \\
\hline Completed annual cycle of care & $\begin{array}{l}\text { No } \\
\text { Yes }\end{array}$ & $\begin{array}{l}1603 \\
846\end{array}$ & $\begin{array}{l}46.6 \% \\
41.9 \%\end{array}$ & $\begin{array}{l}1833 \\
1173\end{array}$ & $\begin{array}{l}53.4 \% \\
58.1 \%\end{array}$ & $\begin{array}{r}1.00 \\
1.21\end{array}$ & $1.07-1.37$ & 0.002 & 0.011 \\
\hline
\end{tabular}

Having completed an ACC was the only variable that was significantly associated with glycaemic control after adjustment for patient characteristics. It is interesting that the only published study that examined the association between the completion of an ACC and health outcomes found that the physical functioning of women with diabetes who had completed an ACC was poorer than in women who had only had their $\mathrm{HbA}_{1 \mathrm{c}}$ levels measured. ${ }^{17}$ Our finding that patients who had completed an ACC were more likely to be in glycaemic control is the first to indicate the usefulness of this quality indicator.
The practice having a chronic disease-focused practice nurse, the practice offering diabetes education sessions for staff, and the practice organising self-management activities for patients with diabetes were features significantly associated with completing an ACC in the univariate model, although the relationship with staff education was not significant in the multivariate model. This highlights the need to have practice nurses trained in chronic disease management. This recommendation is also supported by the finding of a Cochrane review that the addition of patient education or elevating the role of the nurse to involvement in complex intervention strategies seems important for improving both patient outcomes and process outcomes. $^{18}$

It would appear that practice characteristics, apart from those described above, are only weak predictors of the patient having completed an ACC. It is unfortunate that we could not obtain information about individual GPs in each practice, and it is likely that their individual characteristics would have a greater influence on the completion of the ACC than information about the practice as a whole, just as patient 
3 Practice characteristics associated with a completed annual cycle of care (ACC)

\begin{tabular}{|c|c|c|c|c|c|c|c|c|c|}
\hline \multirow[b]{2}{*}{ Variable } & \multirow[b]{2}{*}{ Category } & \multicolumn{2}{|c|}{ ACC completed } & \multicolumn{2}{|c|}{$\begin{array}{l}\text { ACC not } \\
\text { completed }\end{array}$} & \multirow{2}{*}{$\begin{array}{l}\text { Odds } \\
\text { ratio }\end{array}$} & \multirow{2}{*}{$\begin{array}{c}95 \% \\
\mathrm{Cl} \text { for } \\
\text { odds ratio }\end{array}$} & \multirow[b]{2}{*}{$P^{*}$} & \multirow[b]{2}{*}{$P^{\dagger}$} \\
\hline & & $n$ & $\%$ & $n$ & $\%$ & & & & \\
\hline Metropolitan practice & $\begin{array}{l}\text { No } \\
\text { Yes }\end{array}$ & $\begin{array}{c}890 \\
2546\end{array}$ & $\begin{array}{l}58.3 \% \\
64.8 \%\end{array}$ & $\begin{array}{l}636 \\
1383\end{array}$ & $\begin{array}{l}41.7 \% \\
35.2 \%\end{array}$ & $\begin{array}{l}1.00 \\
0.76\end{array}$ & $0.46-1.24$ & 0.202 & \\
\hline Practice size & $\begin{array}{l}1-2 \mathrm{GPs} \\
\geq 3 \mathrm{GPs}\end{array}$ & $\begin{array}{c}854 \\
2568\end{array}$ & $\begin{array}{l}69.5 \% \\
61.0 \%\end{array}$ & $\begin{array}{c}375 \\
1641\end{array}$ & $\begin{array}{l}30.5 \% \\
39.0 \%\end{array}$ & $\begin{array}{l}1.00 \\
1.46\end{array}$ & $0.82-2.59$ & 0.202 & \\
\hline Practice nurse & $\begin{array}{l}\text { No } \\
\text { Yes }\end{array}$ & $\begin{array}{r}654 \\
2739\end{array}$ & $\begin{array}{l}71.7 \% \\
61.4 \%\end{array}$ & $\begin{array}{l}258 \\
1725\end{array}$ & $\begin{array}{l}28.3 \% \\
38.6 \%\end{array}$ & $\begin{array}{l}1.00 \\
1.60\end{array}$ & $0.89-2.88$ & 0.120 & \\
\hline Chronic disease-focused nurse & $\begin{array}{l}\text { No } \\
\text { Yes }\end{array}$ & $\begin{array}{r}690 \\
2746\end{array}$ & $\begin{array}{l}75.5 \% \\
60.5 \%\end{array}$ & $\begin{array}{l}224 \\
1795\end{array}$ & $\begin{array}{l}24.5 \% \\
39.5 \%\end{array}$ & $\begin{array}{l}1.00 \\
2.01\end{array}$ & $1.07-3.77$ & 0.029 & 0.036 \\
\hline $\begin{array}{l}\text { Chronic care planning software } \\
\text { already used }\end{array}$ & $\begin{array}{l}\text { No } \\
\text { Yes }\end{array}$ & $\begin{array}{l}2216 \\
1151\end{array}$ & $\begin{array}{l}63.2 \% \\
61.5 \%\end{array}$ & $\begin{array}{c}1291 \\
721\end{array}$ & $\begin{array}{l}33.3 \% \\
34.5 \%\end{array}$ & $\begin{array}{l}1.00 \\
1.08\end{array}$ & $0.63-1.84$ & 0.792 & \\
\hline Corporate practice & $\begin{array}{l}\text { No } \\
\text { Yes }\end{array}$ & $\begin{array}{c}2922 \\
436\end{array}$ & $\begin{array}{l}61.5 \% \\
78.4 \%\end{array}$ & $\begin{array}{l}1832 \\
120\end{array}$ & $\begin{array}{l}38.5 \% \\
21.6 \%\end{array}$ & $\begin{array}{l}1.00 \\
0.44\end{array}$ & $0.18-1.08$ & 0.073 & \\
\hline Co-located allied health professionals & $\begin{array}{l}\text { No } \\
\text { Yes }\end{array}$ & $\begin{array}{l}1951 \\
1485\end{array}$ & $\begin{array}{l}64.3 \% \\
61.4 \%\end{array}$ & $\begin{array}{c}1084 \\
935\end{array}$ & $\begin{array}{l}35.7 \% \\
38.6 \%\end{array}$ & $\begin{array}{l}1.00 \\
1.13\end{array}$ & $0.69-1.86$ & 0.623 & \\
\hline $\begin{array}{l}\text { Practice involved in quality } \\
\text { improvement collaboration }\end{array}$ & $\begin{array}{l}\text { No } \\
\text { Yes }\end{array}$ & $\begin{array}{l}2326 \\
1093\end{array}$ & $\begin{array}{l}65.3 \% \\
58.5 \%\end{array}$ & $\begin{array}{l}1239 \\
774\end{array}$ & $\begin{array}{l}34.8 \% \\
41.5 \%\end{array}$ & $\begin{array}{l}1.00 \\
1.33\end{array}$ & $0.77-2.31$ & 0.312 & \\
\hline Practice has audit and feedback & $\begin{array}{l}\text { No } \\
\text { Yes }\end{array}$ & $\begin{array}{l}1707 \\
1698\end{array}$ & $\begin{array}{l}64.0 \% \\
61.6 \%\end{array}$ & $\begin{array}{r}960 \\
1059\end{array}$ & $\begin{array}{l}36.0 \% \\
38.4 \%\end{array}$ & $\begin{array}{c}1.00 \\
1.11\end{array}$ & $0.68-1.80$ & 0.677 & \\
\hline $\begin{array}{l}\text { Practice has dedicated case } \\
\text { management }\end{array}$ & $\begin{array}{l}\text { No } \\
\text { Yes }\end{array}$ & $\begin{array}{l}1548 \\
1857\end{array}$ & $\begin{array}{l}59.7 \% \\
65.6 \%\end{array}$ & $\begin{array}{c}1046 \\
973\end{array}$ & $\begin{array}{l}40.3 \% \\
34.4 \%\end{array}$ & $\begin{array}{l}1.00 \\
0.78\end{array}$ & $0.48-1.26$ & 0.301 & \\
\hline $\begin{array}{l}\text { Practice has regular multidisciplinary } \\
\text { team meetings }\end{array}$ & $\begin{array}{l}\text { No } \\
\text { Yes }\end{array}$ & $\begin{array}{c}2499 \\
803\end{array}$ & $\begin{array}{l}66.6 \% \\
55.1 \%\end{array}$ & $\begin{array}{l}1255 \\
654\end{array}$ & $\begin{array}{l}33.4 \% \\
44.9 \%\end{array}$ & $\begin{array}{l}1.00 \\
1.62\end{array}$ & $0.97-2.72$ & 0.068 & \\
\hline Practice has regular staff education & $\begin{array}{l}\text { No } \\
\text { Yes }\end{array}$ & $\begin{array}{l}1639 \\
1766\end{array}$ & $\begin{array}{l}69.5 \% \\
57.6 \%\end{array}$ & $\begin{array}{c}719 \\
1300\end{array}$ & $\begin{array}{l}30.5 \% \\
42.4 \%\end{array}$ & $\begin{array}{l}1.00 \\
1.68\end{array}$ & $1.03-2.73$ & 0.038 & \\
\hline $\begin{array}{l}\text { Practice uses shared electronic } \\
\text { medical records }\end{array}$ & $\begin{array}{l}\text { No } \\
\text { Yes }\end{array}$ & $\begin{array}{l}2239 \\
1187\end{array}$ & $\begin{array}{l}65.0 \% \\
59.6 \%\end{array}$ & $\begin{array}{l}1213 \\
806\end{array}$ & $\begin{array}{l}35.0 \% \\
40.4 \%\end{array}$ & $\begin{array}{l}1.00 \\
1.25\end{array}$ & $0.76-2.08$ & 0.381 & \\
\hline $\begin{array}{l}\text { Practice has patient diabetes } \\
\text { education events }\end{array}$ & $\begin{array}{l}\text { No } \\
\text { Yes }\end{array}$ & $\begin{array}{l}2591 \\
808\end{array}$ & $\begin{array}{l}67.5 \% \\
52.0 \%\end{array}$ & $\begin{array}{l}1245 \\
747\end{array}$ & $\begin{array}{l}32.5 \% \\
48.0 \%\end{array}$ & $\begin{array}{l}1.00 \\
1.92\end{array}$ & $1.21-3.06$ & 0.006 & 0.004 \\
\hline $\begin{array}{l}\text { Practice has self-management } \\
\text { activities }\end{array}$ & $\begin{array}{l}\text { No } \\
\text { Yes }\end{array}$ & $\begin{array}{l}2193 \\
1212\end{array}$ & $\begin{array}{l}65.3 \% \\
58.7 \%\end{array}$ & $\begin{array}{l}1165 \\
854\end{array}$ & $\begin{array}{l}34.7 \% \\
41.3 \%\end{array}$ & $\begin{array}{l}1.00 \\
1.33\end{array}$ & $0.81-2.17$ & 0.262 & \\
\hline
\end{tabular}

characteristics explained more of the variability in glycaemic control than did practice characteristics.

As with all cross-sectional studies, it is unwise to attribute causality to any of the detected associations. Practices nominated themselves to participate in the program, and were thus possibly more interested in diabetes management than those that did not. Finally, practice data, including whether the nurse was a practice nurse or a chronic disease-focused nurse, were self-reported, introducing the possibility of bias; further, the analysed data were based on responses to a checklist of practice attributes completed by practice staff, rather than a direct assessment of these features.

The findings of this study underline the importance of having practice nurses trained in chronic disease management, as well as the practice providing education to its diabetic patients. It is also important that this is the first study to find an association between completion of an ACC and good glycaemic control, and GP practices are therefore encouraged to ensure that their patients with diabetes complete an ACC.

Acknowledgements: Funding for the Diabetes Care Project was received from the Australian Government Department of Health and Ageing.

\section{Competing interests: No relevant disclosures.}

Received 29 Jun 2015, accepted 23 Oct 2015.

(c) 2016 AMPCo Pty Ltd. Produced with Elsevier B.V. All rights reserved. 
1 Australian Institute for Health and Welfare. National health priority areas [website]. 2015. http://www.aihw.gov. au/national-health-priority-areas/ (accessed Sep 2015).

2 Australian Institute for Health and Welfare. Diabetes expenditure in Australia 2008-09, CVD 62, Australia, 2013. Canberra: AlHW, 2013. (AlHW Cat. No. CVD 62.) http://www.aihw.gov.au/ WorkArea/DownloadAsset.aspx?id=6 0129543916 (accessed Sep 2015).

3 Runciman WB, Hunt TD, Hannaford NA, et al. CareTrack: assessing the appropriateness of health care delivery in Australia. Med J Aust 2012; 197: 100-105. https://www.mja.com.au/ journal/2012/197/2/caretrack-assessingappropriateness-health-care-deliveryaustralia

4 Australian Institute for Health and Welfare. Annual cycle of care [website]. 2015. http://www.aihw.gov. au/diabetes-indicators/annual-cycleof-care/ (accessed Sep 2015).

5 Vamos EP, Pape UJ, Bottle A, et al. Association of practice size and payfor-performance incentives with the quality of diabetes management in primary care. CMAJ 2011; 183: E809-E816.

6 Solberg LI, Asche SE, Pawlson LG, et al. Practice systems are associated with high-quality care for diabetes. Am J Manag Care 2008; 14: 85-92.
7 Shojania KG, Ranji SR, McDonald KM, et al. Effects of quality improvement strategies for type 2 diabetes on glycemic control: a meta-regression analysis. JAMA 2006; 296: 427-440.

8 Spigt M, Stefens C, Passage D, et al. The relationship between primary health care organization and quality of diabetes care. Eur J Gen Pract 2009; 15: $212-218$.

9 Scott A, Schurer S, Jensen P, Sivey P. The effects of an incentive program on quality of care in diabetes management. Health Econ 2009; 18 : 1091-1108.

10 Scott A, Coote W. Do regional primary care organisations influence primary care performance? A dynamic panel estimation. Health Econ 2009; 19: 716-729.

11 McKinsey and Company. Evaluation report of the Diabetes Care Project. Canberra: Australian Government Department of Health, 2015. https:// www.health.gov.au/internet/main/ publishing.nsf/Content/302DF0372 F537A43CA257E35000138E8/\$File/ DCP\%20Evaluation\%20Report.pdf (accessed Sep 2015).

12 Precedence Health Care. cdmNet [website]. Melbourne: Precedence Health Care, 2015. http:// precedencehealthcare.com/cdmnet/ (accessed Sep 2015).
13 Australian Bureau of Statistics. Socio-Economic Indexes for Areas [website]. 2013. http://www. abs.gov.au/websitedbs/censushome. nsf/home/seifa (accessed Sep 2015).

14 Loveman E, Royle P, Waugh N. Specialist nurses in diabetes mellitus. Cochrane Database Syst Rev 2003; (2): CD003286.

15 den Engelsen C, Soedamah-Muthu SS, Oosterheert NJ, et al. Improved care of type 2 diabetes patients as a result of the introduction of a practice nurse: 2003-2007. Prim Care Diabetes 2009; 3: 165-171.

16 Juul L, Maindal HT, Frydenberg M, et al. Quality of type 2 diabetes management in general practice is associated with involvement of general practice nurses. Prim Care Diabetes 2012; 6: 221-228.

17 Lowe J, Byles J, Dolja-Gore X, Young A. Does systematically organized care improve outcomes for women with diabetes? J Eval Clin Pract 2010; 16: 887-894.

18 Renders CM, Valk GD, Griffin S, et al. Interventions to improve the management of diabetes mellitus in primary care, outpatient and community settings. Cochrane Database Syst Rev 2001; (1): CD001481. 